\title{
The Course of Biology Learning Methodology: Are Concept-Based Learning and Drill Method Effective in Enhancing Higher-Order Thinking Skills of Students?
}

\author{
Lufri Lufri ${ }^{1}$, Relsas Yogica ${ }^{2}$, Arief Muttaqiin ${ }^{3},{ }^{*}$, Rahmadhani Fitri $^{4}$ \\ \{muttaqiin.a@fmipa.unp.ac.id ${ }^{3, *}$ \}
}

\author{
Department of Biology, Universitas Negeri Padang, Jl. Prof. Dr. Hamka, \\ Indonesia ${ }^{1,2,4}$, Department of Science Education, Universitas Negeri Padang, Jl. Prof. Dr. \\ Hamka, Air Tawar Padang 25131, Indonesia ${ }^{3}$
}

\begin{abstract}
This research aimed to enhance the students' higher-order thinking skills through the Concept-Based Learning and Drill Method in The Course of Biology Learning. The concept-based learning leads students to know the basic concept and avoiding misconceptions, while the drill method is unique due to its characteristics, which make students think higher than before. Therefore, the combination of concept-based learning and drill method was applied in the course of Biology Learning Methodology as an attempt to obtain the positive effect of the strategy. A set of higher-order thinking skills questions were given at the end of the course. The implementation of concept-based learning and drill methods in this course made students obtained a high score in which the average classroom score was 77.87 , classified as $\mathrm{B}+$. Implementing the concept-based learning and drill method can help students in improving their higher-order thinking skills in the Biology Learning Methodology course.
\end{abstract}

Keywords: Concept-Based Learning, Drill Method, Higher Order Thinking Skills

\section{Introduction}

Nowadays, all lecturers at university level need to master 21 st-century skills, so they can train their students to have the 21 st-century skills [1]. One of these skills is to enhance the ability of higher-order thinking skills of students. Lecturers have to be creative in developing the learning process in the classroom to stimulate the higher-order thinking skills of students through some activity which allows students to explore their potential. Providing science activities such as practicum can be utilized to enhance the participation of the students in the classroom [2] and improve their higher-order thinking skills. Applying the activity which increases the students' activity is one of the solutions we can use to provide the experience to our students.

At the university level, students are typically given by learning the material and listen to the explanation from lecturers instead of doing an activity, particularly for the social science subject. Students are provided the number of tasks and need to submit them at the specified time. Most of the students work on a group that has benefits because students have an opportunity to share the ideas with their friends, and collaborative learning which consists of heterogeneous individuals in one group will have a better result than the group with 
homogeneous members [3]. Collaborative learning can be facilitated by learning models such as cooperative learning, which has a strength than traditional learning method [4].

The condition of learning activity in the Biology Learning Methodology course, lecturers convey the learning material using the traditional method. Consequently, students are unable to enhance their capacity to think higher. To encourage students to develop their higher-order thinking, we try to apply the concept-based learning and drill method due to the benefits of these models. Several kinds of research stated that the drill method was sufficient to improve students ${ }^{6}$ understanding in the classroom [5]. Providing problem-solving questions through conceptbased learning and drill methods in the classroom is an effort to enhance the higher-order thinking skills of students in the Biology Learning Methodology course.

\section{Method}

The total sample of the study was 39 students who were provided by the treatment. Students were set to learn the Biology Learning Methodology along one semester and evaluated by higher-order thinking skills assessment and psychological respond questionnaire. The method of this study was The One-Shot Case Study Design [6] which exposed one single group (Figure 1). The concept-based learning and drill methods were applied altogether as the treatment. The university standard (Standard of Universitas Negeri Padang Score) was used to evaluate the final score of students, which will consist of A, A-, B+, B, B-, C+, C, C-, D and E [7]. The average score of the final test was transformed into the appropriate category.

\begin{tabular}{cc}
\hline $\mathbf{X}$ & $\mathbf{O}$ \\
\hline $\begin{array}{c}\text { Concept-Based Learning } \\
\text { and Drill Method }\end{array}$ & Higher-Order Thinking \\
\hline
\end{tabular}

Fig. 1. The treatment and the dependent variable of the study.

The concept-based learning and drill methods were applied altogether as the treatment. The university standard was used to evaluate the final score of students, which will consist of A, A, B+, B, B-, C+, C, C-, D and E (failed). The average score of the final test was transformed into the appropriate category. The parameter of this research was the university standard so that the data would be more natural to be interpreted. Beside it, a psychological respond questionnaire was used as complementary data to explain several factors that can influence the result of the research. The percentage of the aspect related to the treatment would be presented.

\section{Results and Discussions}

The final test was conducted after all of the learning processes were implemented in the Biology Learning Methodology course. As can be seen in Fig.ure 2., the achievement of students after the treatment was proper. Most of the students obtained the A-grade, which means almost excellent. Around $41 \%$ of students achieve the very good grade, B+ and were followed consecutively by $\mathrm{B}$ and $\mathrm{A}$. In total, the average grade of all students score was $\mathrm{B}+$, which means 
that most of the students were very good when the concept-based learning and drill method was applied to the biology learning method course in one semester. No students who obtained the grade under B (good) grade.

During the learning process, the worksheet was given to all of the students. A worksheet is a tool in using concept-based learning and drill methods, which were used in the specified semester. The worksheet required students to think in the right way, using their prior knowledge. There are several questions on the worksheet, and students need to answer all of the completion effectively and quickly. A question has a vital role in encouraging students to think [8], particularly complex thinking. The items in the worksheet consist of the problem-solving questions which require students to think deeply and help them to find the alternatives and solutions to tackle the problem. Furthermore, students were stimulated to improve their higherorder thinking skills when they were exposed by the higher-order thinking skills strategies such as class discussion and dealing the real-world problems to answer the question in the answer sheet [9]. However, higher-order thinking skills, such as critical thinking, are not influenced by their interest in studying the subject [10].

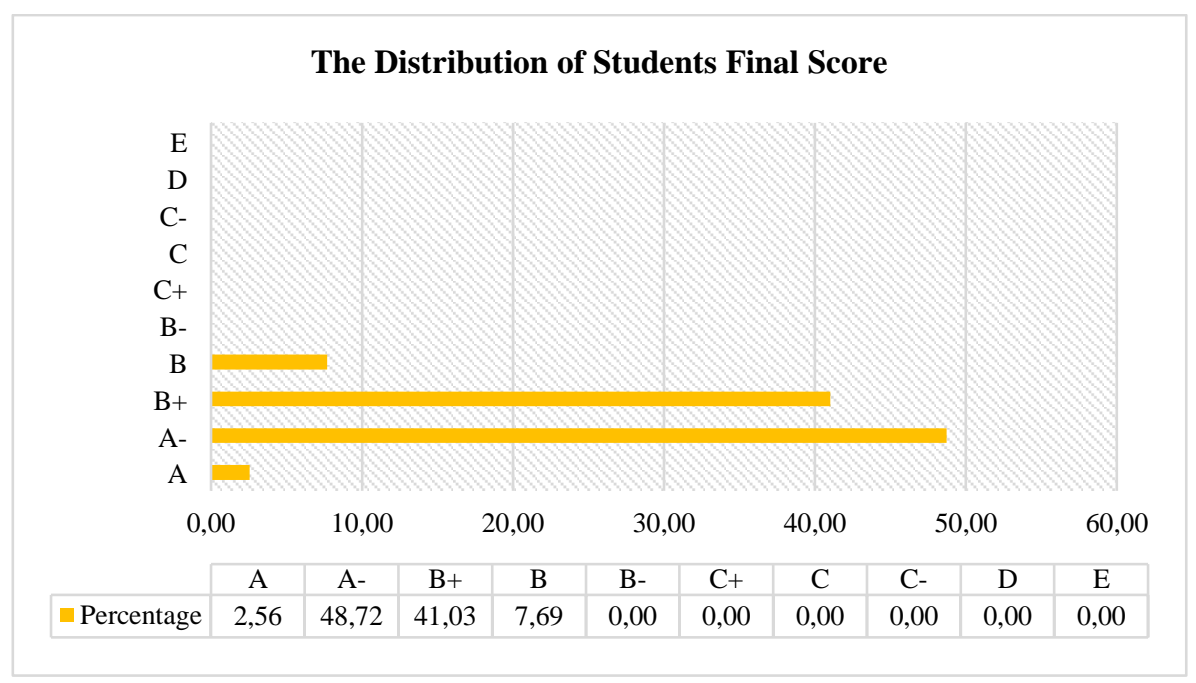

Fig. 2. The distribution of students' final scores in this study.

Further information to support the data was the respond of the students which was captured by a psychological respond questionnaire. As we can see in Table 1, around $84.7 \%$ of students had an excellent perception of the learning material in the Biology Learning Methodology. The learning materials help students to obtain the information and all fundamental concept related to strategy in biology learning. Also, the interest of students in learning material was very good $(81.81 \%)$. The learning material can support students to encourage the intellectual even emotional, which can maximize their learning potentials [11]. Beside it, the response of the students ${ }^{6}$ perception and interest in the learning model as the concern of this research were excellent (85.49\% and $86.94 \%)$. It means that the implementation of the concept-based learning and drill method in this course have a positive response from the students. The excellent response of the students to the learning model indicates that concept-based learning and drill methods are appropriate to be used in their daily learning activities in the classroom. 
Table 1. Psychological responses of students related to the learning process.

\begin{tabular}{cllcl}
\hline No & Aspect & $\begin{array}{l}\text { Score } \\
\text { Average } \\
(1-4)\end{array}$ & Percentage & $\begin{array}{l}\text { Descriptio } \\
\mathrm{n}\end{array}$ \\
\hline 1 & $\begin{array}{l}\text { Students' perception of the learning material } \\
\text { of the Biology Learning Methodology } \\
\text { Students' perception toward the learning } \\
\text { model that is applied by lecturers in the } \\
\text { Biology Learning Methodology course } \\
\text { Students' interest in Biology Learning } \\
\text { Methodology material }\end{array}$ & 3.39 & $84.79 \%$ & Very Good \\
\hline $\begin{array}{l}\text { Students' interest in the learning model that } \\
\text { is applied by lecturers in Biology Learning } \\
\text { Methodology courses }\end{array}$ & 3.48 & $85.49 \%$ & Excellent \\
5 & $\begin{array}{l}\text { Students' attitudes towards Biology } \\
\text { Learning Methodology course }\end{array}$ & 3.22 & $86.94 \%$ & Excellent \\
\hline $\begin{array}{l}\text { Students' attitudes towards learning models } \\
\text { applied by lecturers in Biology Learning } \\
\text { Methodology Subjects }\end{array}$ & 3.23 & $80.76 \%$ & Very Good \\
\hline
\end{tabular}

The questions were given along the learning process which was completed by the worksheet. The worksheet provided the higher-order thinking skill questions and asked students to answer all of the problems. This activity had done as a treatment from the concept-based learning and drill method in the classroom to improve the students' higher-order thinking skills. Providing higher-order thinking skill questions as a task in the classroom can be used as an alternative to involve the student's higher-order thinking skills [12]. The questions (embedded assessment) from worksheet was also convinced can enhance the students' higher-order thinking skill [13].

Overall, students have an impressive perception and interest related to the course. The data support the higher-order thinking skills result, which the way of students to think highly is accomplished. Not only students have a high achievement before, but most of the students gained very good results. The achievement of students to obtain the B+ (very good) indicates that the learning models were successful in being applied in the classroom. The using of learning materials to strengthen the students' comprehension was effective and also the drill method, which was provided many problem-solving questionnaires in the worksheet, was able to boost the higher-order thinking skills of the students.

Based on the result of this study, the concept-based learning and drill method can be applied as the alternative to stimulate students in thinking better than before in understanding the concept of biology learning strategy. Limitations and challenges also exist in this study, such as the lack of students" motivation and focus in the classroom. Providing some questions to the students is a solution that has been applied during the process of the learning process. Giving higher-order thinking skills in the classroom is also good for training students to think continuously. 


\section{Conclusion}

The Biology Learning Methodology course provides essential information to the students to master the foundation of teaching and learning strategy on biology learning. As the teacher candidate, students should master all of the components of biology learning instruction entirely, starting from the learning methods, approaches, models, and evaluation instruments. The concept-based learning and drill method in the classroom is useful to improve students" higherorder thinking skills. Although the standard is not generic, the good domination of students in achieving the scores shows that concept-based learning and drill methods can be applied in the learning. However, there are several limitations, such as the focus of students to learn in some meetings and the motivation of students to learn. They used to be given a stimulation such as a question to increase their participation in the course.

Acknowledgments. Authors thank Direktorat Riset dan Pengabdian Kepada Masyarakat Direktorat Jenderal Riset dan Pengembangan, Kementerian Riset, Teknologi dan Pendidikan Tinggi Republik Indonesia for the funding of this study.

\section{References}

[1] R. E. Borja, "Honing the 21st Century Characteristics of Lecturers in the Faculty of Education for Effective Job Performance,” African Educ. Res. J., vol. 6, no. 3, pp. 160-164, 2018.

[2] C. Espinoza, "Teaching Photosynthesis to Eighth Graders: A Graduate Service-Learning Experience in a Local Science Class,” Purdue J. Serv. Int. Engagem., vol. 4, no. 1, 2017.

[3] L. Cen, S. Ryta, L. Powell, B. Hirsch, and J. Ng, "Quantitative approach to collaborative learning: performance prediction, individual assessment, and group composition,” Int. J. Comput. Collab. Learn., vol. 11, no. 2, pp. 187-225, 2016.

[4] I. Dasdemir, "The Effect of the 5E Instructional Model Enriched with Cooperative Learning and Animations on Seventh-grade Students' Academic Achievement and Scientific Attitudes," Int. Electron. J. Elem. Educ., vol. 9, no. 1, pp. 21-38, 2017.

[5] F. F. Andries, "The Use of Drill Techniques in Teaching Present and Past Tense Private Grammar Toward Students in English Study Program of UNIMA," J. English Lang. Lit. Teach., vol. 4, no. 1, pp. 59-66, 2019.

[6] J. R. Fraenkel, N. E. Wallen, and H. H. Hyun, How To Design and Evaluate Research in Education, 8th ed. New York, USA: The McGraw-Hill Companies, Inc., 2012.

[7] U. N. Padang, "Peraturan Rektor Universitas Negeri Padang Tentang Peraturan Akademik Tentang Penilaian Hasil Belajar di Universitas Negeri Padang." Universitas Negeri Padang, Padang, pp. 1-9, 2017.

[8] H. Terry, "What Is The Purpose Of A Question?" teachtought, 2018. [Online]. Available: https://www.teachthought.com/learning/what-is-the-purpose-of-a-question/. [Accessed: 09-Sep-2019]. [9] B. Miri, B. C. David, and Z. Uri, "Purposely teaching for the promotion of higher-order thinking skills: A case of critical thinking," Res. Sci. Educ., vol. 37, no. 4, pp. 353-369, 2007.

[10] A. Muttaqiin, L. Lufri, and F. R. Rahim, "Critical Thinking Skill of Students on Food Chain Topic and Its Relation to Their Interest," 2019.

[11] Y. M. Harsono, "Developing Learning Materials for Spesific Purpose,” TEFLIN J., vol. 18, no. 2, pp. 169-179, 2007.

[12] A. Zohar and Y. J. Dori, "Higher Order Thinking Skills and Low-Achieving Students: Are They Mutually Exclusive?," J. Learn. Sci., vol. 12, no. 2, pp. 145-181, 2003.

[13] M. Barak and Yehudit J. Dori, "Enhancing Higher Order Thinking Skills Among Inservice Science Teachers Via Embedded Assessment," J. Sci. Teacher Educ., vol. 20, no. 5, pp. 459-474, 2009. 